\title{
Myocyte Enhancer Factor 2C as a Neurogenic and Antiapoptotic Transcription Factor in Murine Embryonic Stem Cells
}

\author{
Zhen Li, ${ }^{1 \star}$ Scott R. McKercher, ${ }^{1 \star}$ Jiankun Cui, ${ }^{1}$ Zhiguo Nie, ${ }^{1}$ Walid Soussou, ${ }^{1}$ Amanda J. Roberts, ${ }^{2}$ Tina Sallmen, ${ }^{1}$ \\ Jeffrey H. Lipton, ${ }^{1}$ Maria Talantova, ${ }^{1}$ Shu-ichi Okamoto, ${ }^{1}$ and Stuart A. Lipton ${ }^{1,2}$ \\ ${ }^{1}$ Center for Neuroscience, Aging, and Stem Cell Research, Burnham Institute for Medical Research, and ${ }^{2}$ Department of Molecular and Integrative \\ Neurosciences, The Scripps Research Institute, La Jolla, California 92037
}

Cell-based therapies require a reliable source of cells that can be easily grown, undergo directed differentiation, and remain viable after transplantation. Here, we generated stably transformed murine ES (embryonic stem) cells that express a constitutively active form of myocyte enhancer factor 2C (MEF2CA). MEF2C has been implicated as a calcium-dependent transcription factor that enhances survival and affects synapse formation of neurons as well as differentiation of cardiomyocytes. We now report that expression of MEF2CA, both in vitro and in vivo, under regulation of the nestin enhancer effectively produces "neuronal" progenitor cells that differentiate into a virtually pure population of neurons. Histological, electrophysiological, and behavioral analyses demonstrate that MEF2C-directed neuronal progenitor cells transplanted into a mouse model of cerebral ischemia can successfully differentiate into functioning neurons and ameliorate stroke-induced behavioral deficits.

Key words: MEF2C; neuronal progenitor cell; embryonic stem cells; neurogenesis; antiapoptotic; transplantation

\section{Introduction}

The adult vertebrate CNS has a limited capacity for self-repair, although neural stem cells (NSCs) persist with regenerative capacity within certain regions of the adult brain (Alvarez-Buylla and Lois, 1995; Lim et al., 1997; Gage et al., 1998; Johansson et al., 1999; Bull and Bartlett, 2005). Nevertheless, in response to injury, NSCs differentiate mainly into astrocytes rather than neurons (Holmin et al., 1997; Johansson et al., 1999; Namiki and Tator, 1999). Thus, development of neuronally restricted progenitor cells would be useful therapeutically (Craig et al., 1996; Kuhn et al., 1997; Magavi et al., 2000; Nakatomi et al., 2002).

Ideal cells to replace lost neurons should be easy to maintain, with efficient and dependable differentiation capacity, lacking neoplastic potential. Disappointingly, although in vitro differentiation of embryonic stem cells (ESCs) can result in nearly pure neuronal cultures (Bibel et al., 2004), the adult CNS presents greater challenges to survival and fate specification. Most cells in transplants die or show glial-restricted differentiation (Fricker et al., 1999; Chow et al., 2000; Cao et al., 2001). However, NSCs

Received Jan. 11, 2008; revised April 23, 2008; accepted May 13, 2008.

This work was supported in part by National Institutes of Health (NIH) Grants P01 HD29587 and R01 NS044326, and a Senior Scholar Award in Aging Research from the Ellison Medical Foundation (S.A.L.). Additional support was provided by the NIH Blueprint Grant for La Jolla Interdisciplinary Neuroscience Center Cores P30 NS057096. We thank Drs. Nobuki Nakanishi, Evan Snyder, Derek van der Kooy, Alexey Terskikh, Juan Piña-Crespo, and Stephen F. Heinemann for helpful discussions.

*Z.L. and S.R.M. contributed equally to this work.

Correspondence should be addressed to Stuart A. Lipton, Burnham Institute for Medical Research, 10901 North Torrey Pines Road, La Jolla, CA 92037. E-mail: slipton@burnham.org.

D01:10.1523/JNEUROSCI.0134-08.2008

Copyright $\odot 2008$ Society for Neuroscience $\quad$ 0270-6474/08/286557-12\$15.00/0 transplanted into brain areas undergoing active neurogenesis can produce significant numbers of region-appropriate neurons (Flax et al., 1998; Fricker et al., 1999; Shihabuddin et al., 2000; Cao et al., 2002). These studies indicate that the host environment plays an important role in determining the fate of engrafted NSCs. The intrinsic state of NSCs also plays a critical role in fate determination (White et al., 2001). Hence, in vitro induction of pluripotent cells into more restricted progenitor cells before transplantation might be necessary for their neuronal differentiation. Nevertheless, lack of directed neuronal differentiation as well as apoptotic cell death remain two major problems in cerebral transplantation.

Our work and that of others suggest that the transcription factor myocyte enhancer factor 2C (MEF2C) may be a candidate for directing neuronal lineage specification during cell replacement therapy while offering antiapoptotic effects to keep the transplanted cells alive after differentiation (Leifer et al., 1993; Schulz et al., 1996; Okamoto et al., 2000; Skerjanc and Wilton, 2000; McKinsey et al., 2002). MEF2 proteins, isoforms A-D, are members of the MADS (MCM1-agamous-deficiens-serum response factor) family of transcription factors (Yu et al., 1992; Naya and Olson, 1999). MEF2 proteins are highly expressed in cardiac myocytes and induce myogenesis from precursor cells (Black and Olson, 1998). Indeed, when we expressed a constitutively active form of MEF2C in P19 teratocarcinoma cells, the result was a differentiated cell with a mixed neuronal and muscle phenotype, including expression of myosin heavy chain protein (Okamoto et al., 2000). MEF2C is the first isoform appearing during neurogenesis in the developing mammalian CNS and has 
recently been implicated in neuronal survival and differentiation, acting as a calcium-dependent factor that protects neurons from apoptotic death (Leifer et al., 1993; Mao and Wiedmann, 1999; Mao et al., 1999; Okamoto et al., 2000).

MEF2 proteins were recently reported to regulate activitydependent synapse formation (Flavell et al., 2006; Shalizi et al., 2006), and can act synergistically with the ubiquitous transcription factor Sp1 to influence the restricted expression of a great many neuron-specific genes (Krainc et al., 1998; Okamoto et al., 2000, 2002; Allen et al., 2002). These findings are consistent with the notion that MEF2 proteins regulate neuronal development not only by promoting survival but also by inducing differentiation.

Here, using a constitutively active form of MEF2C (MEF2CA), we report the production and characterization of neuronally restricted progenitors derived from non-oncogenetransformed, murine embryonic stem (ES) cells, and their subsequent successful transplantation into a disease model of focal cerebral ischemia.

\section{Materials and Methods}

Propagation and maintenance of undifferentiated ES cells. The undifferentiated mouse D3 ES cell line of low passage number (6-11) was grown on $1 \%$ gelatin and maintained in DMEM plus $20 \%$ FCS culture medium containing leukemia inhibitory factor (LIF) $(1000 \mathrm{U} / \mathrm{ml})$, as previously described (Nagy et al., 1993).

Neural cell fate specification of transiently transfected ES cells. One day before transfection, mouse D3 ES cells were trypsinized and plated in DMEM plus 20\% FBS and $1000 \mathrm{U} / \mathrm{ml}$ LIF in six-well tissue culture plates coated with gelatin at a density resulting in $\sim 90 \%$ confluency within $1 \mathrm{~d}$. Cultures were washed with OptiMEM medium without antibiotics, and then Lipofectamine 2000 transfection reagent (Invitrogen) mixed with nestin/thymidine kinase (tk)-enhanced green fluorescent protein (EGFP), nestin/tk-MEF2CA, or nestin/tk-Bcl-xL $(1.6 \mu \mathrm{g}$ of DNA/10 $\mu \mathrm{l}$ of Lipofectamine) was added and incubated at $37^{\circ} \mathrm{C}, 5 \% \mathrm{CO}_{2}$ for $4 \mathrm{~h}$. The medium was then changed to DMEM plus $20 \%$ FBS (without LIF), and the cells were allowed to recover in the incubator overnight. The transfected cells were trypsinized and plated at limiting dilution to obtain single cells for lineage analysis into 24 -well plates on poly-D-lysine (PDL)-coated glass coverslips in DMEM with added glutamine but without serum or growth factors, as previously described (Tropepe et al., 2001). The 24 -well plates were placed into a $37^{\circ} \mathrm{C}, 5 \% \mathrm{CO}_{2}$-humidified incubator for 2-24 h. At various time points, coverslips were removed, fixed and stained with Hoechst dye and antibodies reactive against various neuronal and non-neuronal markers. Transfected cells were identified by expression of EGFP. Control and experimental values for each replicate experiment were compared for statistical differences using a one-tailed Student's $t$ test.

Generation of stable MEF2CA-expressing ESC-derived neuronal progenitor cells. Mouse D3 ES cells were trypsinized to single cells and washed with PBS. Pelleted cells were then transfected with nestin/tk-MEF2CA, nestin/tk-MEF2DN (dominant negative), or nestin/tk-EGFP by electroporation $(0.25 \mathrm{kV} ; 500 \mathrm{mF})$; cotransfection with pSVneo was performed to allow selection of clones. Cells were resuspended in growth medium at a concentration of $5-7 \times 10^{5}$ cells $/ \mathrm{ml}$. Using a plastic pipette, $10 \mathrm{ml}$ of ES cells were placed in $100 \mathrm{~mm}$ bacterial grade dishes to allow the cells to aggregate in suspension culture in the absence of LIF. This stage is defined as day 0 of embryoid body (EB) differentiation. On day 2, EBs were collected into a conical tube. After 5 min, EBs formed sediment at the bottom of the tube, and the supernatant was aspirated. Fresh medium was added, and the EBs were transferred to a new bacterial dish. On day 4 , the above steps were repeated, and all-trans retinoic acid was added to a final concentration of $10^{-6} \mathrm{M}$. On day 6 , to eliminate nontransfected cells, $200 \mu \mathrm{g} / \mathrm{ml}$ Geneticin (G418) was added, and the EBs were maintained for 2 more days. Clones showing the highest expression of EGFP were chosen for additional expansion and differentiation experiments.

Lineage selection, expansion and differentiation of purified stably trans- fected neuronal progenitor cell lines. EGFP-positive EBs were trypsinized and triturated into single cells, washed, centrifuged, and resuspended in a chemically defined serum-free medium as previously described (Reynolds and Weiss, 1992). Serial dilutions were made and plated at clonal (single cell) density in microtiter plates (Nunclon). Mitotic neural progenitor clones were selected and expanded based on their responsiveness to FGF2 and epidermal growth factor (EGF) on the plastic tissue culture surface pretreated with PDL and laminin in serum-free DMEM/F12 with $1 \times \mathrm{N} 2,20 \mathrm{ng} / \mathrm{ml} \mathrm{FGF} 2,20 \mathrm{ng} / \mathrm{ml} \mathrm{EGF}, 1 \mu \mathrm{g} / \mathrm{ml}$ heparin, and $200 \mu \mathrm{g} / \mathrm{ml}$ G418. FGF2, EGF, and G418 were added each day at concentrations of 20 $\mathrm{ng} / \mathrm{ml}, 20 \mathrm{ng} / \mathrm{ml}$, and $200 \mu \mathrm{g} / \mathrm{ml}$, respectively. Additionally, two-thirds of the medium volume was exchanged every other day. Differentiation of these cells was performed by removing the mitogenic factors and plating on poly-L-lysine/laminin substrate-coated glass coverslips, either as intact clusters or dissociated cells, in serum-free or low serum-containing (2-5\%) medium.

In vitro immunocytochemistry. Cultured cells were fixed for $20 \mathrm{~min}$ in $4 \%$ paraformaldehyde in $\mathrm{PBS}$ at $4^{\circ} \mathrm{C}$. Perfused brain tissue was postfixed in $4 \%$ paraformaldehyde overnight, equilibrated in $30 \%$ sucrose in PBS at $4^{\circ} \mathrm{C}$, frozen in OCT, and cut on a cryostat into $16 \mu \mathrm{m}$ sections. The following primary antibodies were used to stain fixed cells on glass coverslips and perfused, cryoprotected brain sections: anti-nestin rat monoclonal (1:300; Developmental Hybridoma Bank), anti-microtubule associated protein-2 (MAP-2) mouse monoclonal (1:300; Sigma-Aldrich), anti-glial fibrillary acidic protein (GFAP) mouse monoclonal (1:500; Sigma-Aldrich), anti- $\beta$ III-tubulin (TuJ1) monoclonal (1:1000; Covance; reacts with neuron-specific tubulin), anti-doublecortin (Dcx) goat polyclonal (1:100; Santa Cruz Biotechnology), anti-MASH1 mouse monoclonal (1:250; BD Pharmingen), anti-neural cell adhesion molecule (NCAM) mouse monoclonal (1:100; Developmental Hybridoma Bank), anti-neurofilament 200 (NF) mouse monoclonal (1:300; SigmaAldrich), anti-myosin heavy chain (MHC) mouse monoclonal (1:300; Santa Cruz Biotechnology), anti-VP16 mouse monoclonal (1:300; Santa Cruz Biotechnology), anti-neuronal nuclear protein (NeuN) mouse monoclonal (1:100; Millipore Bioscience Research Reagents), anti-MEF2 goat polyclonal (1:1000; Santa Cruz Biotechnology), anti-GFP goat polyclonal (1:300; Santa Cruz Biotechnology), and anti-bromodeoxyuridine (BrdU) (1:300; Accurate). Appropriate fluorescently tagged secondary antibodies (Jackson ImmunoResearch Laboratories) were used at a dilution of 1:500 and incubated for $3 \mathrm{~h}$ at room temperature or overnight at $4^{\circ} \mathrm{C}$. Cultures were finally incubated in Hoechst 33258 nuclear stain $(0.015 \mathrm{mg} / \mathrm{ml}$ stock solution diluted to $0.001 \mathrm{mg} / \mathrm{ml}$; Roche Diagnostics) or 4,6, diamidino-2-phenylindole (DAPI) (300 nM in PBS; Invitrogen) to facilitate cell quantification and viability assessment. Control cultures were processed simultaneously using identical protocols without primary antibodies. Specimens were examined on a Leica DC480 or Zeiss Axiovert 100M deconvolution imaging system (SlideBook Software; Intelligent Imaging Innovations).

Morphometric assessment of neurite outgrowth. Morphometric assessment of neurite outgrowth was performed on areas selected randomly using an Axiovision image analyzer (Zeiss), as previously described (Oh et al., 1996). The length of the primary neurite was defined as the distance from the soma to the tip of the longest branch. At least one neurite had to be longer than the width of the cell body in order for a cell to be scored as having a neurite. Control and experimental values for each replicate experiment were compared for statistical differences using a one-tailed Student's $t$ test.

In vitro electrophysiology. Cultured MEF2CA-expressing ESC-derived neuronal progenitor cells (MEF2CA-ESC-derived NPCs) were plated onto 12 -mm-diameter glass coverslips coated with poly-L-lysine/laminin or on a glial feeder layer. In the latter case, we cultured mouse embryonic cortical astrocytes (embryonic day 14) for 7-10 d in vitro (DIV) before plating MEF2CA-ESC-derived NPCs. Whole-cell recordings were performed at room temperature, as previously described (Lei et al., 1992; Lipton et al., 1993; Kim et al., 1999; Choi et al., 2000). Coverslips with cells were placed in a recording chamber with a volume of $\sim 150 \mu \mathrm{l}$. The recording chamber was mounted on the stage of a Zeiss Axiovert inverted microscope. Electrical signals were amplified using an Axopatch 200B amplifier (Molecular Devices) and filtered at $2 \mathrm{kHz}$ via a Bessel low-pass 
filter. Data were sampled and analyzed using pClamp9 or 10.1 software (Molecular Devices). The patch pipettes were pulled from standard wall glass $1.5 \mathrm{~mm}$ in outer diameter (Warner) with final tip resistance of 4-10 $\mathrm{M} \Omega$. In general, for recording voltage-gated $\mathrm{Na}^{+}$currents, we used the following intracellular solution (in mM): $120 \mathrm{CsCl}, 20$ tetraethylammonium chloride (TEA-Cl), 10 HEPES, 2.25 EGTA, $1 \mathrm{CaCl}_{2}, 2 \mathrm{MgCl}_{2}, \mathrm{pH}$ adjusted to 7.4 with $\mathrm{CsOH}$. To elicit voltage-gated currents, we used 100 $\mathrm{ms}$ depolarizing steps from -60 to $+30 \mathrm{mV}$ in $10 \mathrm{mV}$ increments after a $300 \mathrm{~ms}$ prepulse to $-90 \mathrm{mV}$. For observing action currents under voltage clamp, a $\mathrm{KCl}$-based solution without TEA was substituted for the $\mathrm{CsCl} /$ TEA solution. For recording ligand-gated currents, the intracellular solution contained the following (in $\mathrm{mM}$ ): 130 Cs-gluconate, $2 \mathrm{MgATP}, 1$ $\mathrm{MgCl}_{2}, 10$ EGTA, 10 HEPES, $\mathrm{pH}$ adjusted to 7.25 with $\mathrm{CsOH}$. Osmolarity was adjusted to $300 \mathrm{mOsm}$ with sucrose. The bath solution contained a saline based on $\mathrm{HBSS}$ (in mM: $137 \mathrm{NaCl}, 1 \mathrm{NaHCO}_{3}, 0.34 \mathrm{Na}_{2} \mathrm{HPO}_{4}, 2.5$ $\mathrm{KCl}, 0.44 \mathrm{KH}_{2} \mathrm{PO}_{4}, 2.5 \mathrm{CaCl}_{2}, 5$ HEPES, 22.2 glucose, $\mathrm{pH}$ adjusted to 7.3 with $\mathrm{NaOH}$ ). Receptor agonists and antagonists were prepared in bath solution and applied by an array of tubes placed $50-75 \mu \mathrm{m}$ from the cells. Drug administration was controlled by a series of rapidly triggered valves (Lee Company; Warner Instruments). Solution changes were achieved within 50-100 ms, and a pipette containing bath solution was used to rapidly wash out applied drugs.

Transient middle cerebral artery occlusion/reperfusion. All animal procedures were approved by the Burnham Administrative Panel on Laboratory Animal Care. Transient middle cerebral artery occlusion (tMCAO) (Longa et al., 1989; Soriano et al., 1996; Wang et al., 1998) was induced in adult male C57BL/6 mice (25-35 g) under isoflurane anesthesia in a mixture of oxygen and nitrous oxide (30:70). A small incision was made in the neck of an anesthetized mouse and a 6.0 silicone-coated monofilament (Johnson \& Johnson) was inserted into the common carotid artery up to the circle of Willis to occlude the ostium of the middle cerebral artery for $60 \mathrm{~min}$. Sham operations consisted of the same procedure but the filament was removed immediately. To determine changes in regional cerebral blood flow (rCBF), we used a laser Doppler flowmeter (BPM; Vasamedica) with a $0.7 \mathrm{~mm}$ Probe (P433; Vasamedica). The skull was exposed through a midsagittal incision, and the probe tip placed on the skull surface $3 \mathrm{~mm}$ lateral to the midline and 2 $\mathrm{mm}$ posterior to the bregma. These cortical coordinates represent the ischemic core of the infarct (Wang et al., 1998; Gu et al., 2005). rCBF was recorded during occlusion and immediately after reperfusion, falling to virtually $0 \%$ during occlusion while recovering during reperfusion to at least $75 \%$ of its initial value. After the $60 \mathrm{~min}$ occlusion, animals were tested to ensure that behavioral deficits were present, including spontaneous circling and limited forelimb flexion. Mice were then reanesthetized and the filament was removed. Mice were monitored daily for postoperative recovery and neurological function (Modo et al., 2000).

Transplantation of NPCs. One day after the tMCAO procedure, the reperfused mice were anesthetized with isoflurane, as above. Animals were placed in a stereotaxic frame and an incision was made, exposing the bregma. A burr hole was drilled for insertion of the needle for injection of cells into the striatum on the ipsilateral side. Deposition of $\sim 50,000$ cells/ $\mu \mathrm{l}$ was made in a $1 \mu \mathrm{l}$ volume at a rate of $1 \mu \mathrm{l} / \mathrm{min}$. The needle was left in place for $2 \mathrm{~min}$ after injection to permit dispersion of the cells and prevent back leakage.

In vivo electrophysiology. Electrophysiological recordings were performed on $400-\mu \mathrm{m}$-thick cortical slices at $32^{\circ} \mathrm{C}$. Whole-cell recordings with patch electrodes were performed in either current- or voltage-clamp mode. The external (bath) solution contained the following (in mM): 125 $\mathrm{NaCl}, 2.5 \mathrm{KCl}, 2 \mathrm{CaCl}_{2}, 1 \mathrm{MgCl}_{2}, 1.25 \mathrm{NaH}_{2} \mathrm{PO}_{4}, 26 \mathrm{NaHCO}_{3}, 25$ glucose; saturated with $95 \% \mathrm{O}_{2}$ and $5 \% \mathrm{CO}_{2}$ at $\mathrm{pH}$ 7.4. The internal (patch pipette-filling) solution contained the following (in $\mathrm{mM}$ ): 125 potassium gluconate, $5 \mathrm{KCl}, 10$ HEPES, 1 EGTA, $2 \mathrm{Na}_{2} \mathrm{ATP}, 2 \mathrm{MgATP}$, and 10 sodium phosphocreatine at $\mathrm{pH}$ 7.2. To monitor action potentials under current clamp, depolarizing current steps were applied from a resting potential of approximately $-60 \mathrm{mV}$ after a hyperpolarizing prepulse. To record spontaneous EPSCs (sEPSCs), the recording mode was switched to voltage clamp, and the resting membrane potential was held at -60 $\mathrm{mV}$. The observed synaptic currents were not inhibitory (sIPSCs) because they persisted as inward currents when clamped to $-30 \mathrm{mV}$, which is above the reversal potential for IPSCs. To characterize the pharmacology of the sEPSCs, CNQX and D-(-)-2 amino-5-phosphonovaleric acid (D-APV) were added to block AMPA and NMDA receptors, respectively.

Neurobehavioral analysis. A standard contextual/cued fear conditioning test was performed, essentially as previously described (Roberts et al., 2004). Briefly, mice were divided into three cohorts: sham transient middle cerebral artery occlusion/reperfusion (tMCAOR); tMCAOR plus injection of MEF2CA/EGFP-ESC-derived neuronal progenitor cells; and tMCAOR plus injection of EGFP-ESC-derived neural progenitor cells. Conditioning experiments commenced 6-8 weeks after cell transplantation in a chamber within a sound-proof box. The conditioning chamber had a speaker mounted on two opposite walls plus a shockable grid floor. Mice were placed in the conditioning chamber for $2 \mathrm{~min}$ before onset of a discrete conditioned stimulus ( $30 \mathrm{~s}$ at $3 \mathrm{kHz}, 80 \mathrm{~dB}$ sound). During the last $2 \mathrm{~s}$ of the conditioned stimulus, the mice were exposed to a $0.70 \mathrm{~mA}$ current footshock. After pairing the conditioned stimulus with the footshock, the mice were left in the conditioning chamber for another $30 \mathrm{~s}$ and then returned to their home cages. For contextual conditioning, freezing was measured for $5 \mathrm{~min}$ in the chamber in which the mice were trained. For cued conditioning, the mice were placed in a novel context [the chamber disguised by new walls, a new floor, and a novel odor (orange extract)] for $3 \mathrm{~min}$, after which the mice were exposed to the conditioned stimulus (tone) for $3 \mathrm{~min}$. Both contextual and cued conditioning were assessed by measuring freezing at $5 \mathrm{~s}$ intervals. Testing was performed $12 \mathrm{~h}$ (for contextual conditioning) or $24 \mathrm{~h}$ (for cued conditioning) after training. Extinction of the conditioned fear response was achieved by 20 repeated placements back into the shocking chamber, measuring freezing time during each placement. Statistical significance was assessed by ANOVA followed by a post hoc Scheffé test.

\section{Results}

\section{ES cells transiently transfected with MEF2CA show increased expression of neuronal markers and resist apoptosis after removal of growth factors}

To assess the potential antiapoptotic and neurogenic roles of MEF2C in early neuronal development, the following plasmids were constructed in the pcDNA3 vector: MEF2CA-IRES-EGFP, substituting the transactivation domain of MEF2C for the Herpes virus VP16 sequence to make MEF2 constitutively active; Bcl-xLIRES-EGFP; and EGFP. Expression of all transgenes was under the regulation of the tk minimal promoter and nestin second intron enhancer. Nestin is a gene expressed in neural stem/progenitor cells. The second intron of the nestin gene is sufficient to target gene expression to neuroepithelial progenitor cells (Lothian and Lendahl, 1997) and is conserved between rodents and humans. The EGFP construct represents a transfection control, whereas Bcl-xL expression inhibits apoptosis, thus allowing us to distinguish this process from neuronal differentiation, although Bcl-xL has recently been implicated in neuronal differentiation in immortalized ES cells (Liste et al., 2007). Mouse D3 embryonic stem cells were transfected with the plasmids, allowed to recover overnight in DMEM plus 20\% serum without LIF, and then replated without serum or growth factors after limiting dilution to virtually single-cell density to avoid cell-cell contact. These conditions are a modification of those developed for clonal analysis of mouse embryonic stem cells to demonstrate a neural "default" differentiation process (Tropepe et al., 2001).

After $2 \mathrm{~h}$ of culture in serum/growth factor-free medium, immunocytochemistry showed that nearly all cultured cells, regardless of the gene transfected (EGFP; Bcl-xL; MEF2CA), expressed the early neural stem/progenitor cell marker, nestin (data not shown). After $4 \mathrm{~h}$ in culture, only $\sim 10 \%$ of the cells transfected with any of the constructs had undergone apoptosis based on assessment of condensation of Hoechst-stained nuclei (Fig. $1 A, B)$. Over the next $20 \mathrm{~h}$, the percentage of cells surviving decreased for all transfections. However, after $24 \mathrm{~h}$ in culture, the 
percentage of surviving $\mathrm{Bcl}-\mathrm{xL}$ and MEF2CA transfected cells remained statistically equivalent $(\sim 60 \%)$, whereas the percentage of surviving EGFP control cells decreased significantly to $\sim 35 \%$ (Fig. $1 B$ ). Thus, the cells expressing MEF2C survived at a rate equivalent to those expressing antiapoptotic Bcl-xL.

Importantly, during this time period, immunocytochemical experiments demonstrated that expression of neuronalspecific markers, including the early postmitotic neuronal marker TuJ1 and the mature neuronal markers MAP-2, NeuN, and NF, were all highly expressed in MEF2CA-transfected cells but not in control EGFP- or Bcl-xL-transfected cells (Fig. $1 C)$. In contrast, GFAP, which is an astrocyte marker in this context but which also is found in a population of neural progenitor cells that can differentiate into either neurons or astrocytes (Doetsch et al., 1999), was rarely found in MEF2CA transfected cells. However, GFAP was prominently expressed in the two differentiating control cell lines, suggesting that most of these cells were committed to the astrocyte lineage. The non-neural, muscle-specific marker MHC was not detected in cells of any of these cultures, indicating that differentiation was not misdirected toward a muscle phenotype. These results show that transient expression of MEF2CA in ES cells, as they are released from their differentiation block by removal of LIF from the medium, and then cultured in the absence of serum and all other exogenous growth factors, not only enhances cell survival but also directs the fate of ES cells toward neuronal differentiation.

Generation of MEF2C stably transfected neural progenitor cell lines from mouse ES cells

The results of the transient transfection experiments suggested that creation of cell lines that were stably transfected with the MEF2CA gene might provide a renewable source of cells that would be preferentially directed toward neuronal commitment and protected against apoptosis. To that end ES cells were engineered with MEF2CA-EGFP, a dominant-negative form of MEF2 (MEF2DN-EGFP), or the EGFP reporter gene alone under the control of the nestin/tk promoter. The dominant negative represents a MEF2C construct that consists of only the DNA binding domain with no transactivation domain, and thus serves as an interfering form to block MEF2 function (Ornatsky et al., 1997; Okamoto et al., 2002). Our technique for generating neural progenitor
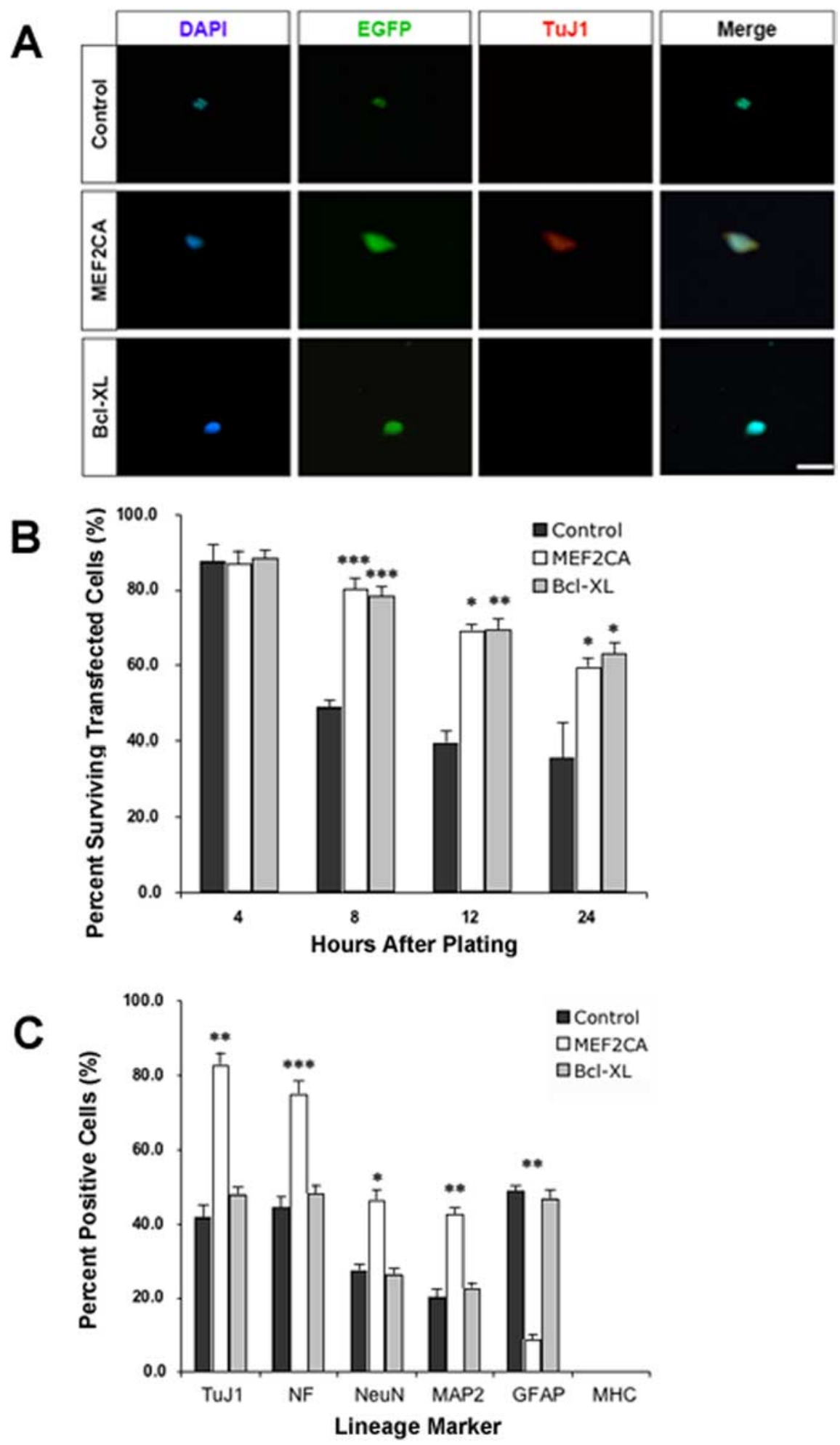

Figure 1. Forced expression of MEF2CA in ES cells plated at limiting dilution enhances survival and neuronal differentiation. $\boldsymbol{A}$, Representative micrographs of murine D3 ES cells transiently transfected with expression plasmids containing EGFP (control), EGFP/MEF2CA, or EGFP/BCl-xL under regulation of the nestin promoter. The ESCs were allowed to recover and then plated at a limiting dilution in defined medium without serum or growth factors. Cells were stained with DAPI for nuclear morphology and TuJ1 as evidence for neuronal differentiation. $\boldsymbol{B}$, Percentage of surviving cells, treated as described above, quantified after culture for various time periods. C, Percentage of surviving cells $24 \mathrm{~h}$ after plating as described above and stained with markers for neurons (TuJ1, NeuN, NF, and MAP-2), astrocytes/progenitor cells (GFAP), or muscle (MHC). Results are expressed as mean + SEM from three separate experiments. Statistical significance different from control cells was as follows: ${ }^{*} p<0.05,{ }^{* *} p<0.01$, ${ }^{* * *} p<0.001$. Scale bars, $25 \mu \mathrm{m}$. 
A
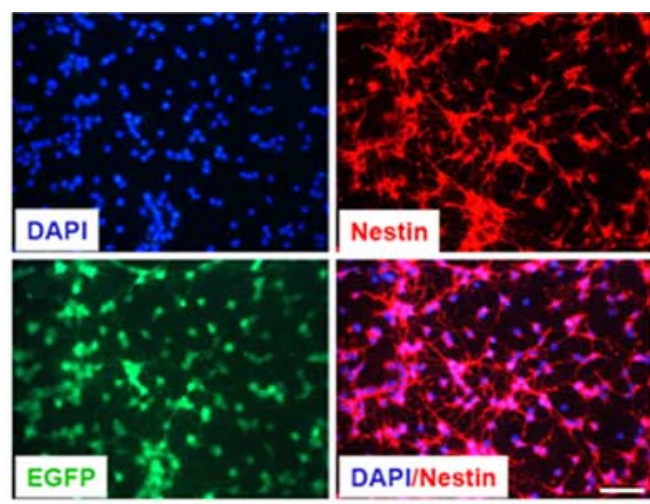

B
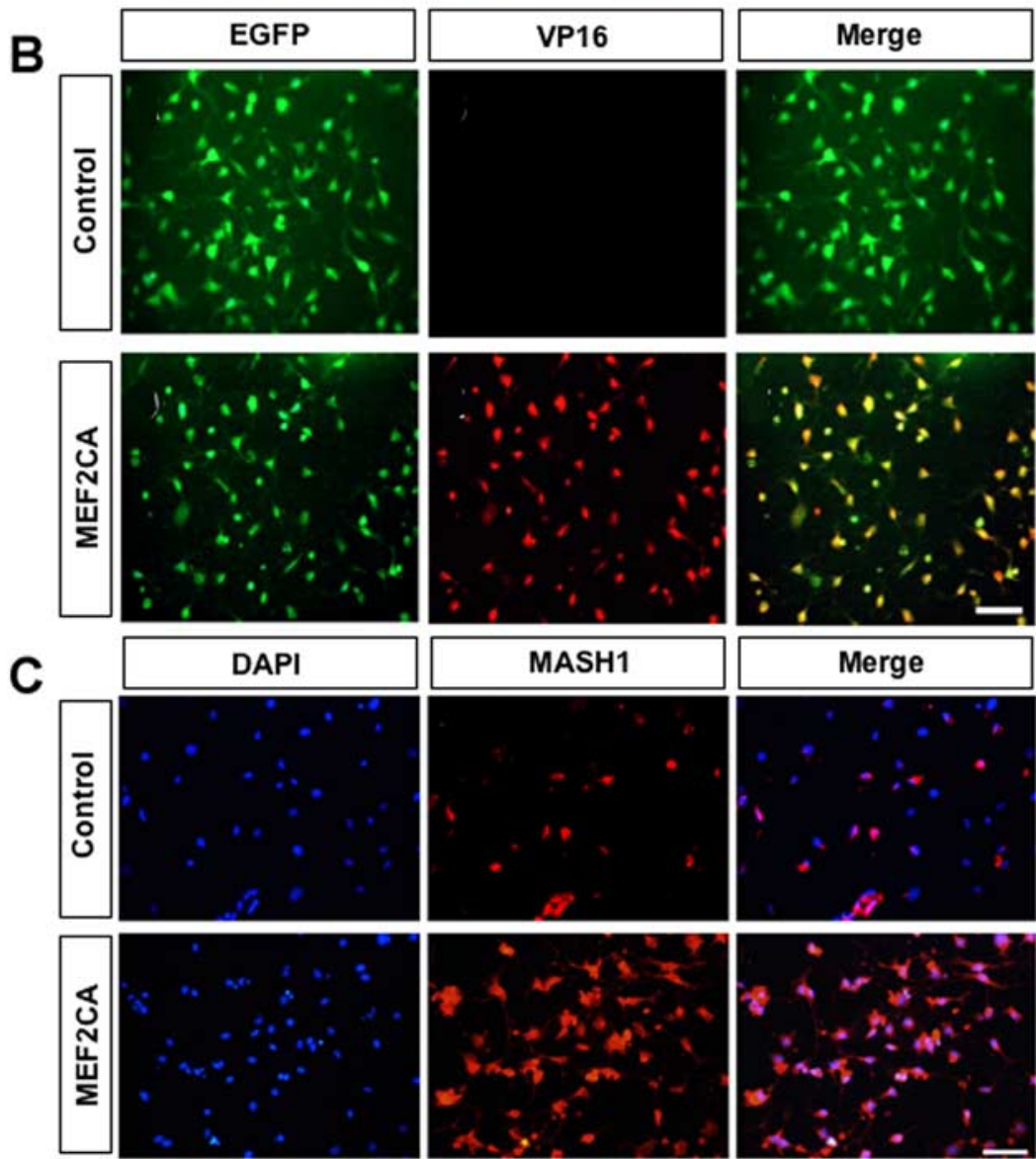

Figure 2. Effect of expression of EGFP/MEF2CA in nestin-positive neural progenitor cells derived from stably transfected ES cells. MEF2CA-ESC-derived or control EGFP-ESC-derived "neurospheres" were mechanically dissociated and plated on poly-L-lysine-coated glass coverslips and cultured for $2 \mathrm{~d}$ in medium containing FGF2 and EGF. $A$, Cells stained with DAPI and an antibody against nestin. $\boldsymbol{B}$, MEF2CA/EGFP-ESC-derived neural progenitors express the constitutively active form of MEF2C (as evidenced by anti-VP16 antibody staining). In contrast, MEF2CA protein could not be detected in control neural progenitor cells. C, MEF2CA-ESC-derived neural progenitors express MASH1, a transcription factor that interacts with MEF2 during DNA binding. Scale bar, $50 \mu \mathrm{m}$ (all panels).

cells from the transfected ES cells followed previously published methods (Bain et al., 1995; Okabe et al., 1996; Li, 2002). No cells expressing MEF2DN survived the selection procedure, thereby recapitulating in differentiating ES cells our previous results that were obtained in differentiating P19 cells and in developing cerebrocortical neurons, showing that MEF2 is an important antiapoptotic/prosurvival factor and that cells die when its function is disrupted (Okamoto et al., 2000, 2002).

Seven ESC-derived, stably transfected MEF2CA neural progenitor cell lines thus produced were characterized as expressing
EGFP and the intermediate filament protein nestin, which is found in neural precursor cells (Fig. $2 A$ ). These cells also expressed the constitutively active form of MEF2C as evidenced by their positivity for VP16 protein (Fig. 2 B). The expression of the bHLH (basic helix-loop-helix) transcription factor Mash1 is considered to be important in determining whether neural progenitors ultimately generate neurons or glia (Parras et al., 2002; Murray et al., 2003). MASH1 was reported to regulate the expression of specific genes that are critical for neuronal differentiation via a cooperative interaction with members of the MEF2 family of transcription factors (Black et al., 1996; Mao and Nadal-Ginard, 1996). Two days after plating in FGF2 plus EGF-containing medium, the proneuronal gene MASH1 was highly expressed in virtually all MEF2CA-ESC-derived neural progenitor cells, but in many fewer control cells (Fig. 2C).

\section{MEF2CA-expressing ESC-derived neural progenitors differentiate primarily along the neuronal lineage}

MEF2CA/EGFP-positive neural progenitor cells and EGFP-positive control neural progenitor cells generated from undifferentiated ES cells were both FGF2- and EGF-responsive, as shown by their continued viability in suspension culture as clusters or "neurospheres" in the presence of these mitogens.

Two days after the removal of mitogens to allow for differentiation, we investigated the lineage characteristics of the cells, which had begun to display neuritic-like processes, by quantitative immunocytochemistry with a variety of antibodies to neuronal and non-neuronal specific genes. As shown by representative micrographs in Figure $3 A$, a large percentage of differentiating MEF2CAESC-derived cells were strongly positive for the early postmitotic neuronal marker TuJ1. Many fewer control cells showed similar expression of TuJ1. Similarly, three other markers that are expressed by neuronal cells, Dcx, a protein expressed in migrating neurons (Gleeson et al., 1998, 1999), highly polysialylated neural cell adhesion molecule (PSA-NCAM), seen on neuronally committed progenitors or immature neurons (Gotz, 2003), and MAP-2, were more widely expressed in these differentiating MEF2CA-ESC-derived neural progenitor cells than in the control EGFP-ES-derived progenitor cells (Fig. $3 B, E$ ). To examine possible non-neuronal cell fates of differentiating control and MEF2CA-neural progenitor cells, we determined the expression of GFAP and MHC. MHC was chosen because MEF2 isoforms are also known regulators of muscle cell differentiation (Black and Olson, 1998). GFAP expression was found in only a very small percentage of MEF2CAneural progenitor cells, whereas the vast majority of control cells expressed this protein (Fig. 3C). The muscle-specific protein MHC was not detectable in either control or MEF2CA cells (Fig. $3 D)$. Quantification of the immunofluorescence data are illustrated in Figure 3E. These results were also confirmed by immunoblot analysis (data not shown).

Morphologic observation of cells plated from the TuJ1- 
positive cells of Figure 3 showed many extended processes after $24 \mathrm{~h}$ in culture (Fig. $4 A-D$ ). Morphometric analysis of the plated cells after 1 and $2 \mathrm{~d}$ in culture demonstrated that more than twice as many of the MEF2CA cells displayed neuritic-like processes as did the control cells (Fig. 4E).

Together, these results suggest that expression of constitutively active MEF2C in early neural development directs these progenitor cells toward neuronal differentiation and that these stable cell lines are therefore indeed committed neuronal progenitors. Moreover, forced expression of MEF2CA did not promote misdirected differentiation into either other cell fates or tumor cells. Thus, we designated these MEF2CA-transfected ESC-derived cells as "neuronal progenitor" lines, in contrast to the standard neural progenitor cells, which can generate either neurons or glia. To further prove this premise, we next investigated the electrophysiological properties of these lines as they differentiated in vitro.

\section{In vitro differentiated, MEF2CA-ESC-derived neuronal progenitors display electrophysiological characteristics of developing neurons}

Expression of neuron-specific proteins is suggestive of neuronal development, but the unique electrophysiological signature of neurons is a more definitive indication of differentiation into the neuronal phenotype. Stable neuronal progenitor cells expressing MEF2CA (MEF2CA-ESC-derived NPCs) were differentiated as described in the Materials and Methods and cultured for up to 5 weeks. We used patch electrodes to record in the wholecell configuration from cells labeled with EGFP and displaying morphological characteristics of neurons (Fig. 5A). Under current clamp, compared with mature cortical neurons with resting membrane potentials of $-60 \mathrm{mV}$ (Lei et al., 1992; Lipton et al., 1993), these cells generally had lower resting membrane potentials, in the -30 to -40 $\mathrm{mV}$ range, probably reflecting their still immature neuronal nature and high input resistance (Esposito et al., 2005). Under voltage clamp, however, we observed robust tetrodotoxin (TTX)-sensitive sodium currents with fast time course, typical of neurons (Fig. $5 B, C$ ). Additionally, Figure 5, $D$ and $E$, shows representative traces from cells manifesting ligand-gated currents on exposure to the neurotransmitters GABA or glutamate, respectively. Glutamate-induced currents in these cells were completely blocked by D-APV, indicating the presence of NMDA-type glutamate channels (Fig. $5 E$ ). After 2-3 weeks in culture, $30-40 \%$ of the cells manifested such GABA- or glutamate-evoked currents.

MEF2CA-ES-derived NPCs survive and differentiate in ischemic mouse brain in vivo, displaying electrophysiological properties of integrated neurons

To investigate the fate of the MEF2CA-ESC-derived NPCs in vivo, we induced ischemic brain damage in adult male mice by tMCAOR procedure, which simulates a human stroke in many $\left.{ }^{*} p<0.001\right)$.
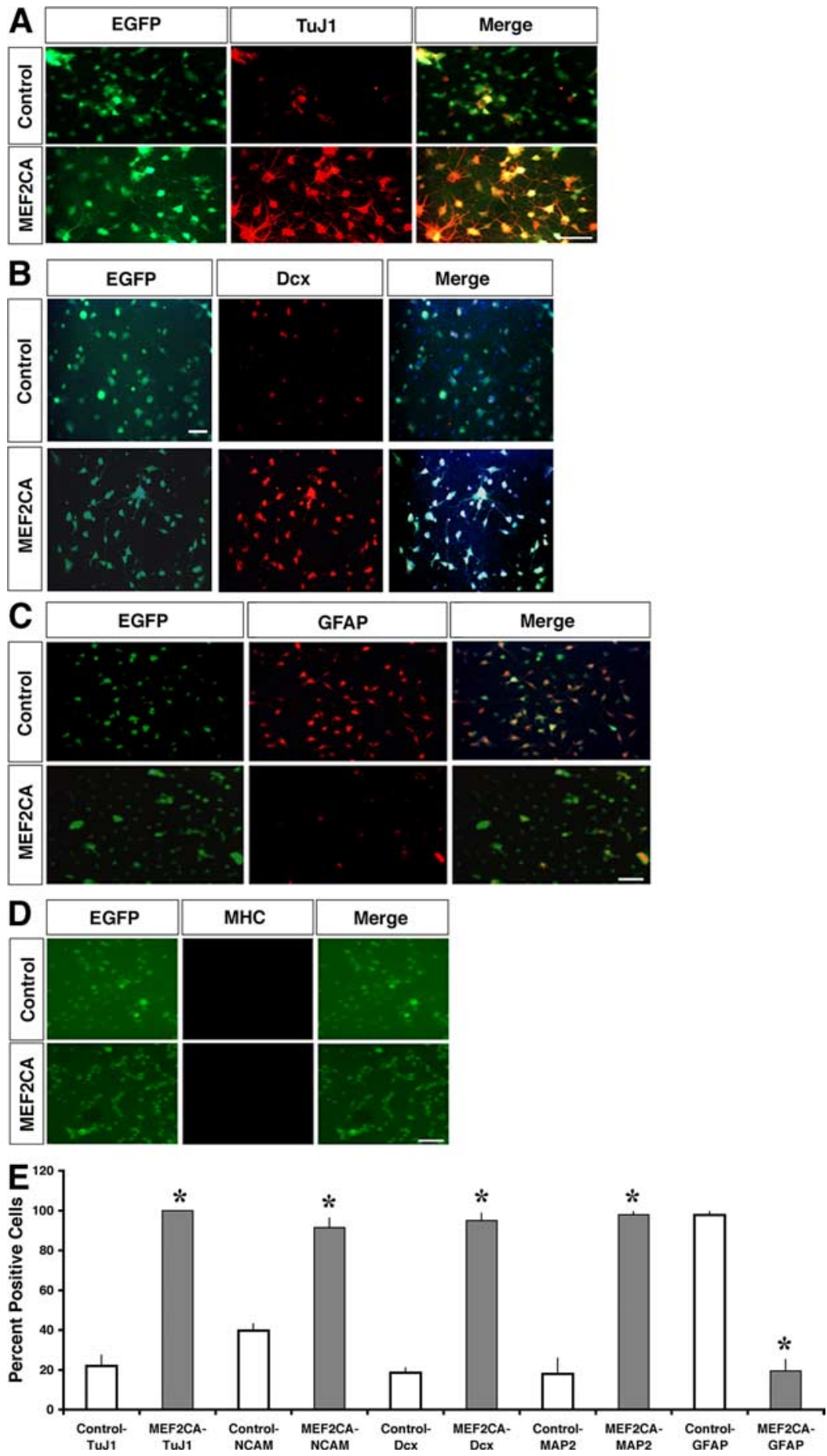

Figure 3. Enhanced neuronally restricted gene expression in cultured MEF2CA-expressing ESC-derived neural progenitor cells. $\boldsymbol{A}-\boldsymbol{D}, \mathrm{MEF} 2 \mathrm{CA}$-expressing or control (EGFP-expressing) neural progenitor cells were cultured for $2 \mathrm{~d}$ in the absence of mitotic factors and then fixed and stained with antibodies against TuJ1 (A), Dcx (B), GFAP (C), or MHC (D). Scale bar, $50 \mu \mathrm{m}$ (all panels). $\boldsymbol{E}$, Quantitation of immunofluorescent stainings. Values are mean + SEM $(n=4$;

ways (Longa et al., 1989; Wang et al., 1998). These mice were injected with $\sim 50,000$ cells of EGFP-ESC-derived control neural progenitor cells or MEF2CA-EGFP-ESC-derived NPCs. Since the nestin promoter regulated expression of EGFP and MEF2CA, the expected downregulation of expression of EGFP during differentiation could have proven problematic for detection of engrafted cells many months after their differentiation in vivo. We therefore used a variety of 


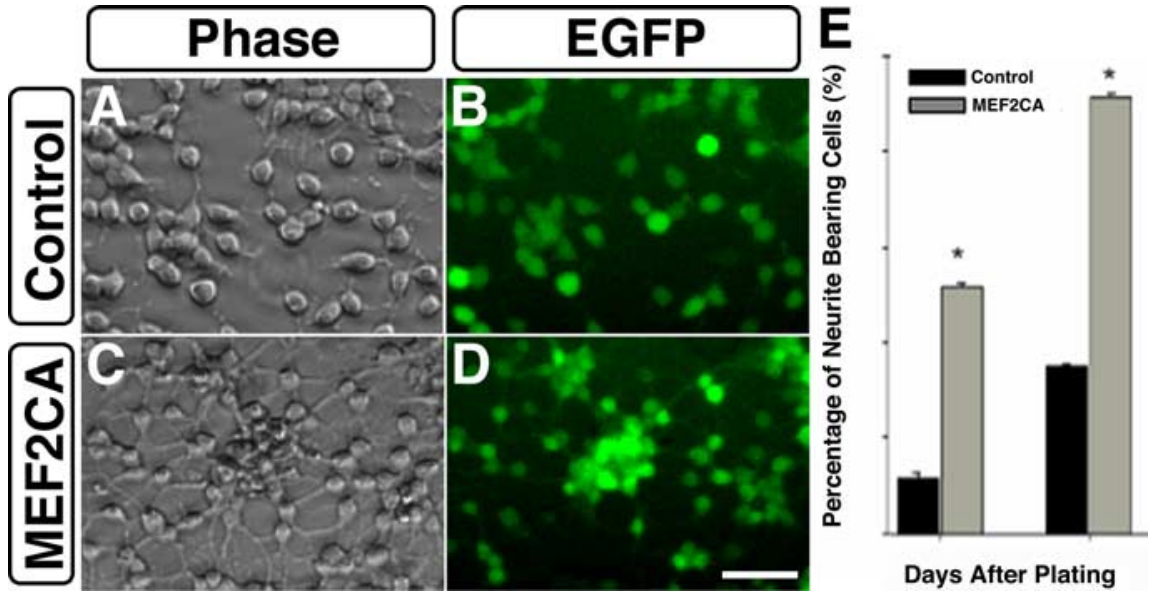

Figure 4. Expression of MEF2CA in ESC-derived neural progenitor cells stimulates the growth of neuritic processes. Morphological and morphometric assessment of differentiating stably transfected neural progenitors revealed that MEF2CA/EGFP-expressing cells developed many more neurites than cells expressing EGFP alone. After culturing from dissociated neurospheres, cells were deprived of mitotic factors (EGF and FGF2) for $2 \mathrm{~d}$ to decrease proliferation and allow differentiation. $\boldsymbol{A}-\boldsymbol{D}$, Phase and epifluorescence views of cells with neurites. $\boldsymbol{E}$, Quantitative assessment of neurite outgrowth 1 and $2 \mathrm{~d}$ after plating. Percentage of neurite-bearing cells is expressed as mean + SEM from five separate experiments. ${ }^{*} p<0.001$ above control cultures. Scale bar, $50 \mu \mathrm{m}$ (all panels).
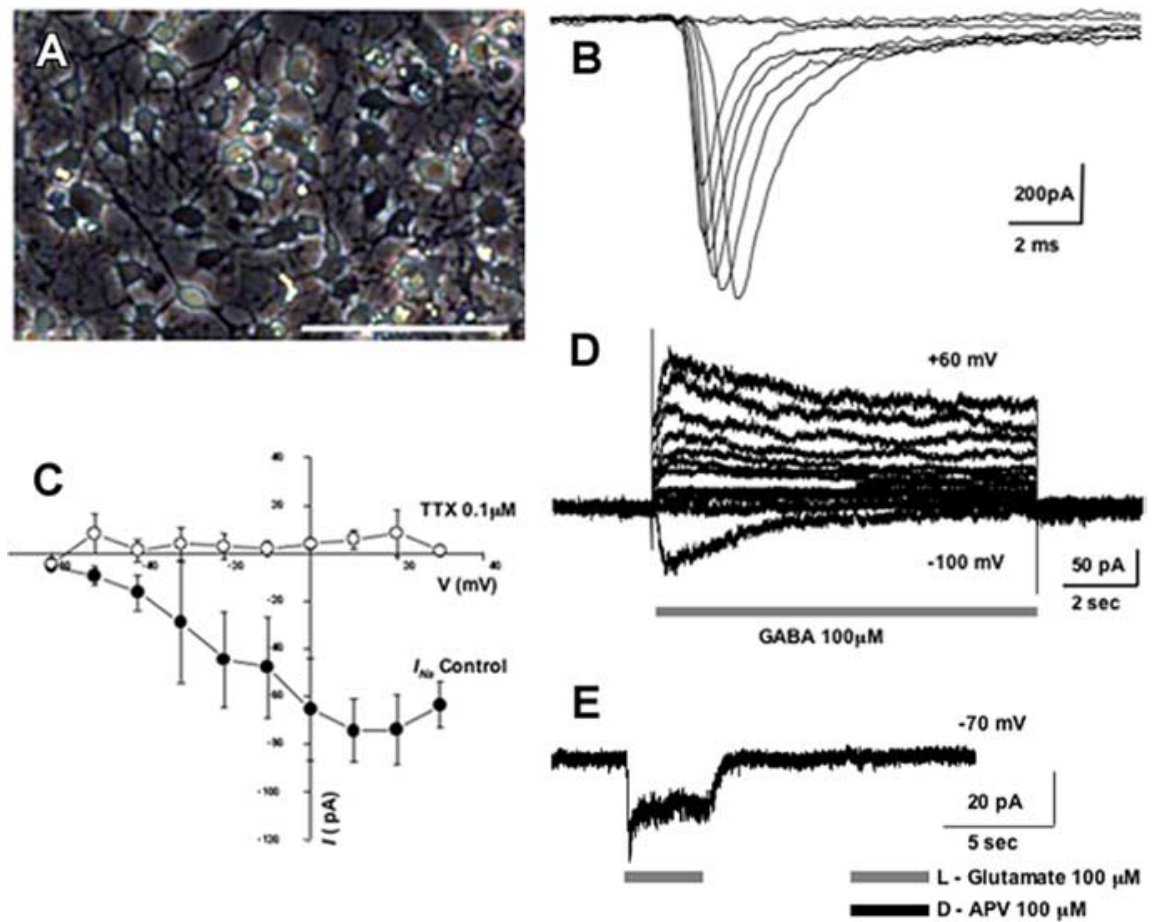

Figure 5. Electrophysiological properties of in vitro differentiated MEF2CA-ESC-derived neuronal progenitor cells. MEF2CA-ESC-derived NPCS were plated on glass coverslips coated with poly-L-lysine and laminin $(\boldsymbol{A}-\boldsymbol{C})$ or on a feeder layer of astrocytes to promote synaptic contacts $(\boldsymbol{D}, \boldsymbol{E})$ and allowed to differentiate. $\boldsymbol{A}$, Appearance of MEF2CA-ESCderived NPCs in culture for $\sim 2$ weeks. Scale bar, $100 \mu \mathrm{m}$. $\boldsymbol{B}$, Representative whole-cell recordings of $\mathrm{Na}^{+}$currents evoked by voltage steps in $10 \mathrm{mV}$ increments from a holding potential of $-60 \mathrm{mV}$ after a $300 \mathrm{~ms}$ prepulse to $-90 \mathrm{mV}$. C, Current/voltage (I/V) relationship of peak amplitude of action currents reveals a TTX-sensitive component representing $\mathrm{Na}^{+}$current $(n=3)$. Error bars indicate SEM. D, GABA-evoked currents after 16 DIV recorded under voltage clamp in the whole-cell configuration. GABA-evoked responses exhibited a reversal potential around $-70 \mathrm{mV}$, consistent with the notion that the current was carried predominantly by $\mathrm{Cl}^{-}$under these conditions $(n=4)$. $E$, Glutamate-evoked currents after 23 DIV were inhibited by APV, indicating the presence of NMDA channels $(n=9)$. Glutamate-evoked currents were recorded in the presence of $20 \mu \mathrm{m}$ glycine and no added $\mathrm{Mg}^{2+}$. strategies for secondary labeling of the cells to be engrafted before their transplantation. Cells were secondarily labeled with BrdU, CellTracker, or Q(uantum dot)Tracker 525 (Invitrogen), or by transduction with a lentiviral construct constitutively expressing EGFP. Cells were injected in a $1 \mu \mathrm{l}$ volume along the anterior-posterior axis of the nonischemic portion of the ipsilateral cortex $1 \mathrm{~d}$ after a $60 \mathrm{~min}$ tMCAO and $24 \mathrm{~h}$ reperfusion.

At $1 \mathrm{~d}$ posttransplantation, all EGFPpositive cells remained clustered at the injection site or along the needle track. Stained brain sections analyzed 4 weeks postinjection revealed that most of the transplanted MEF2CA-ESC-derived NPCs (identified by BrdU labeling) that remained at the injection site expressed the immature neuronal marker TuJ1 (Fig. 6A). In contrast, very few control EGFP engrafted cells at the injection sites expressed TuJ1 (Fig. 6B). By 8 weeks posttransplantation, we found that many of the engrafted MEF2CA-ESC-derived NPCs (labeled here with lentiviral EGFP) now expressed the postmitotic neuronal protein $\mathrm{NeuN}$ and were located throughout the brain, particularly near the ischemic zone (Fig. 6C). Colocalization of EGFP and NeuN can be clearly observed in the high-magnification inset (Fig. 6D). So many labeled transplanted cells were observed in these sections that it is unlikely that cell fusion could have accounted for these findings (Terada et al., 2002; Ying et al., 2002).

For electrophysiological experiments, we prepared coronal brain slices from mice previously transplanted with MEF2CAESC-derived NPCs labeled with QTracker. A labeled preparation of cells expelled onto a culture dish before transplantation is shown in Figure 7A. Within 8 weeks of injection, MEF2CA-ESC-derived NPCs that had been labeled with quantum dots developed a neuronal morphology with long processes (Fig. 7B). To study neuronally related excitability in individual cells, we obtained whole-cell recordings with patch electrodes and depolarized labeled cells versus endogenous host neurons in the current-clamp mode to trigger action potentials (Fig. 7C). To observe ligand-gated synaptic currents, we recorded from the labeled cells in the voltage-clamp mode (Fig. $7 D)$. sEPSCs were observed that were blocked by a combination of CNQX plus D-APV. These data suggest that at least some of the engrafted cells developed synaptic connections with the host brain mediated by glutamate receptors of the AMPA and NMDA subtypes. 


\section{Behavioral improvements in mice receiving MEF2CA-ESC-derived NPC transplants}

Next, to ask whether engrafting cells into ischemic areas of the brain resulted in improved function, we executed neurobehavioral paradigms. To address this question, we performed the tMCAOR procedure on two cohorts of mice, while one cohort received a sham procedure. Six to 8 weeks later, mice were tested with a cued and context conditioning fear response regimen (Paylor et al., 1994; Roberts et al., 2004). Fear conditioning tests measure a highly conserved behavior of amygdalar and hippocampal origin with relevance to humans (Sotres-Bayon et al., 2004) and thus represent a robust neurobehavioral battery to assess improvement after stroke. In the cued conditioning experiments, we found that transplantation of the MEF2CA-ESC-derived NPCs resulted in significant improvement in extinction of the fear response over mice receiving transplants of control cells not transduced with MEF2CA, although the level of performance did not reach that of the sham-treated (nonstroke) control mice (Fig. 7E). These results suggest that MEF2CA expression in the transplanted cells was a significant factor in ameliorating this ischemia-induced learning deficit.

\section{Discussion}

Using a constitutively active form of the transcription factor MEF2C, we demonstrate production of the first stably transformed, ESC-derived, pure neuronal progenitor cell lines, designated MEF2CA-ESC-derived NPCs. We present evidence for the neuronal character of these cells after differentiation not only by neuronal markers but also from electrophysiological properties of these cells, both in vitro and in vivo. In vivo, we transplanted the MEF2CA-ESC-derived NPCs as a proof-of-principle therapy for stroke in a mouse tMCAO/reperfusion model and subsequently found improved neurobehavioral indices.

Stroke is a major cause of death and disability, but, despite intensive studies, few treatment options exist. Fetal brain tissue transplants have been shown to produce some recovery in animal models of stroke (Piccini et al., 1999; Lindvall and Hagell, 2000), but ethical considerations and a short supply of human fetal tissue limit this approach. Self-renewing and multipotent neural progenitor cells that give rise to neurons, astrocytes, and oligodendrocytes have been found in the fetal and adult mammalian brain, including humans and rodents. Thus, the neural progenitor cell is likely to be a promising source of donor cells for brain transplantation. Embryonic stem cell cultures can be a nearly unlimited source of pluripotent cells, but the key to their successful use lies in the ability to control their differentiation and avoidance of tumor formation. Ideally, cells for transplantation into the brain would be differentiated to a stage at which they are neurally restricted in their potential and expandable for production of large numbers. Also, it is necessary to provide mechanisms of control over the transplanted cells so that they can be directed toward the desired lineage, either neuronal or glial, and protected from induced apoptosis in the "hostile" environment of the mature brain. In the present report, we describe results that show that expression of constitutively active MEF2 drives differentia- tion of mouse embryonic stem cells along a neuronal lineage, and that stable transformation of these ESC-derived neural progenitors with the MEF2C gene results in "neuronal progenitor" cell lines (NPCs) that can be grown indefinitely in culture. We observed that the forced expression of constitutively active MEF2C in the neural progenitors has the effect of greatly biasing the differentiation pathway toward neurons and protecting the cells from apoptosis in vitro and in vivo after transplantation. It has recently been posited that new glial cells can originate from reactive gliosis, for example after a stroke, possibly obviating the need to specifically transplant this cell type (Buffo et al., 2008). Additional experiments will be required to confirm or disprove this supposition in our system.

Previously, using a combined molecular and bioinformatics approach, we found that a large number of neuronally restricted genes have MEF2 sites in their promoter regions and lack a TATA box (Krainc et al., 1998; Okamoto et al., 2000). This fact had first suggested to us that MEF2 might play a very important role in neurogenesis. Additionally, multiple MEF2 binding sites are located in the regulatory region of the BclxL gene (S.-i. Okamoto and S. A. Lipton, unpublished observation). Bcl-xL is an antideath member of the Bcl-2 family (Boise et al., 1993; Frankowski et al., 1995; Gonzalez-Garcia et al., 1995; Krajewski et al., 1995a,b; Roth et al., 1996). Expression of such Bcl-2 family members in response to MEF2 activity may in fact protect new endogenous neurons after stroke, and permit additional neurogenesis, suggesting a possible feedback loop (Zhang et al., 2006). Combining 

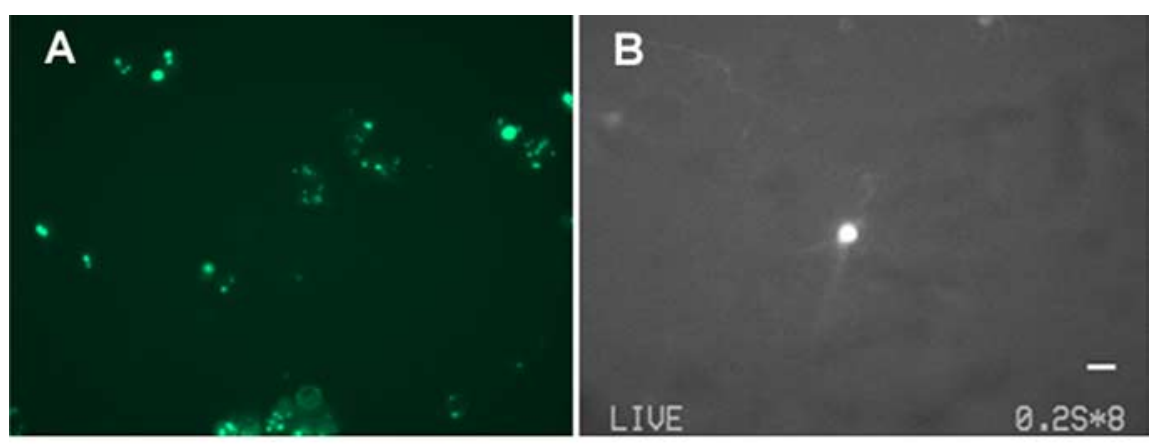

C
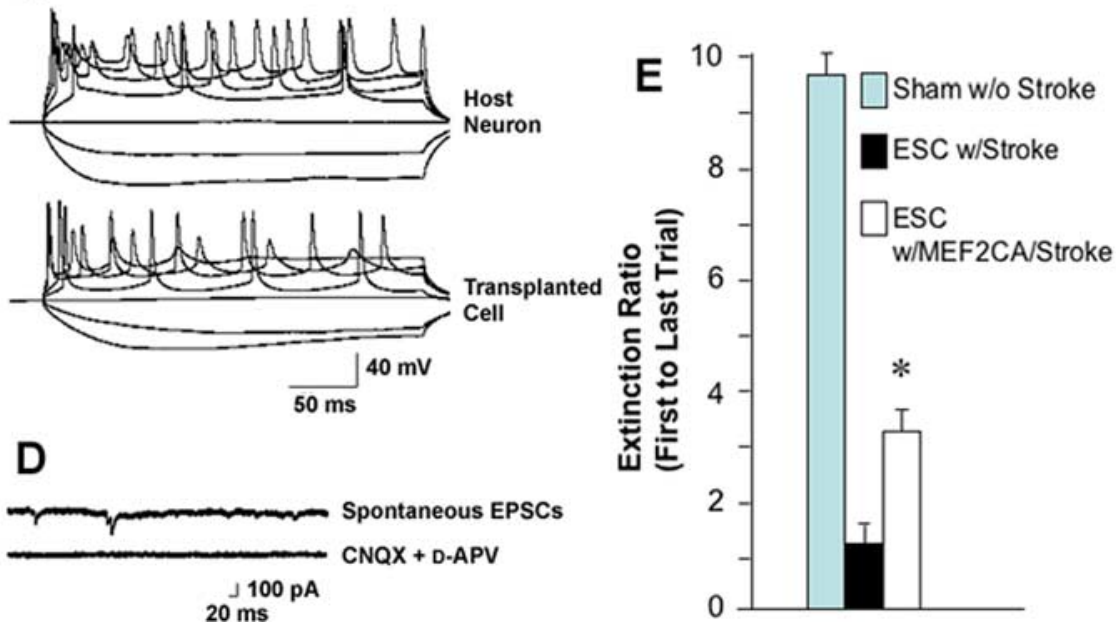

Figure 7. MEF2CA-ESC-derived neuronal progenitor cells injected into ischemic mouse brain manifest electrophysiological properties of integrated neurons and improve behavior. A, MEF2CA-expressing cells labeled with Qtracker 525 (Invitrogen) before injection. $\boldsymbol{B}$, Representative transplanted cell containing quantum dots visualized live using a FITC filter in an acute cortical brain slice obtained 6 weeks after injection into the striatum of the mouse stroke model. Careful inspection reveals the presence of long fluorescent processes emanating from the cell body. Scale bar, $10 \mu \mathrm{m}$. Similar cells were recorded from in the electrophysiological traces shown below. For this purpose, we selected engrafted cells that were isolated from others to carefully characterize their potential integration into the surrounding endogenous neuronal network by assessing synaptic activity. $\boldsymbol{C}$, During whole-cell recording in the current-clamp mode, both endogenous unlabeled neurons (top trace) and transplanted green cells (bottom trace) displayed similar trains of action potentials, which were elicited by injection of depolarizing current, and passive voltage responses to hyperpolarizing current $(n=6$ cells). $\boldsymbol{D}$, Under voltage clamp, an engrafted (green) cell in a cortical slice was held at $-60 \mathrm{mV}$, and sEPSCs were observed (top trace). These synaptic currents were completely blocked by perfusion in a combination of $10 \mu \mathrm{m}$ CNQX and $50 \mu \mathrm{m}$ D-APV (bottom trace; $n=3$ cells). $\boldsymbol{E}$, Three months after tMCAOR and injection of either MEF2CA/EGFP-ESC-derived NPCs or EGFP-expressing progenitor cells, or sham surgery, mice underwent a standard neurobehavioral battery of fear conditioning and were then tested for extinction of the fear response ( $n=10$ for each group; ${ }^{*} p<$ 0.01). Error bars indicate SEM.

these various lines of evidence, it was reasonable for us to hypothesize that MEF2 could be used as a transgene to protect neural progenitor cells during transplantation from apoptosis and to promote their neuronal differentiation.

We reasoned that, for effective transplantation, forced expression of MEF2 should be restricted to the progenitor stage of differentiation to protect the cells and force commitment at this critical stage, but then allow the inherent differentiation programs to run once the cells were localized in the damaged brain. Nestin is an early filament gene that is expressed primarily in neural progenitor cells; the nestin enhancer sequence therefore was a driver that met our requirements. We therefore created constructs with the nestin enhancer sequence and tk minimal promoter driving either EGFP alone for a control, or constitutively active MEF2C-IRES-EGFP. The present results demonstrate for the first time that constitutively active MEF2C (MEF2CA) regulated by the nestin enhancer not only promotes survival but also drives undifferentiated ES cells toward a neuro- nal phenotype in the absence of the influence of serum, growth factors, or a feeder layer. Most of the ES cells in our hands expressed nestin after removal of LIF from the medium, concordant with the idea of a neural "default" differentiation pathway (Tropepe et al., 2001). Since the nestin/tk promoter drives our MEF2CA transgene, it was actively transcribed in these transiently transfected cells. However, in the absence of serum or growth factors, the improved survival and more pronounced bias toward neuronal development in cells expressing MEF2CA shows that this transgene was driving neurogenesis and protecting the cells from apoptosis. The antiapoptotic activity of MEF2CA that we observed was as effective as that of transfected nestin/tkBcl-xL (Fig. $1 B$ ), but under our conditions the Bcl-xL-transfected cells displayed a much stronger tendency to become progenitor or glial lineage cells (i.e., expressing GFAP in Fig. 1C), again emphasizing that in contrast MEF2CA expression promotes neurogenesis.

Our results with the transient transfection of ES cells suggested a strategy for generating stable cell lines predisposed to neuronal differentiation, which would be a potentially useful material for transplantation to correct neuronal damage caused by degenerative disease or trauma. The nestin/ tk-MEF2CA-EGFP transgene was stably integrated into ES cells and used to generate and select nestin-positive neuronal progenitor cell lines that recapitulated the transient transfection results. These EGFP marked cells represented proliferative neuroepithelial cells that expressed nestin and were maintained as "neurospheres" in culture medium containing FGF2 and EGF with minimal differentiation through at least eight passages in culture. Removal of the mitotic factors caused the cells to attach to substrate and differentiate. Downregulation of the nestin/tk transgene (coupled to MEF2CA/EGFP or EGFP alone) occurred on differentiation into neuronal or glial cell phenotypes. The nestin/tk-EGFP control cell lines generated mostly GFAP-positive glial cells with few neurons. In contrast, the proportion of cells expressing the neuronal markers $\mathrm{TuJ} 1$ and MAP-2 greatly increased in cell lines expressing the nestin/tkMEF2CA-EGFP construct. Importantly, MEF2CA-expressing cells did not express muscle-specific myosin heavy chain (Fig. $3 D$ ), as was the case with expression of MEF2CA in P19 teratocarcinoma cells (Okamoto et al., 2000). Because MEF2 is also known to be an essential regulator of muscle development, this result shows that expression of the MEF2CA transgene in neural progenitors did not result in misdirected differentiation.

These MEF2CA-ESC-derived NPCs also produced more prominent neurite outgrowth on differentiation. Differentiating the MEF2CA-ESC-derived NPCs on poly-L-lysine/laminincoated glass coverslips produced cells that not only displayed neuronal proteins by immunocytochemistry but also electro- 
physiological characteristic of neurons, including TTX-sensitive fast sodium currents, and GABA- or glutamate-evoked currents.

In vitro studies can only provide a limited amount of information regarding the potential fates and effects of transplanted cells. It is well established that transplantation studies in mice require some form of brain damage to potentiate engraftment; mature cells transplanted into normal brains do not survive. In contrast, intracerebrally transplanted mouse ESCs, neural progenitor cells, or v-myc immortalized neuroepithelial stem cells migrate toward a site of pathological injury (Villa et al., 2000; Hoehn et al., 2002; Modo et al., 2002). Although the precise mechanism of migration of engrafted cells is unclear, it is possible that both the inflammatory response and intrinsic properties of the transplanted cells could play a role (Svendsen et al., 1996, 1997; Armstrong et al., 2000; Li et al., 2000; Chen et al., 2001; Li, 2002). To assess our MEF2CA-ESC-derived NPCs in vivo, we chose transplantation into the mouse tMCAOR stroke model, a procedure that produces reproducible ischemic damage to one cerebral hemisphere with distinct behavioral deficits.

The transplanted MEF2CA-ESC-derived NPCs that we characterized in the ischemic brains manifested a neuronal phenotype, as assessed by immunohistochemistry and electrophysiology. Moreover, the presence of synaptic currents suggested that the cells had started to integrate into the neuronal network of the host the brain. The formation of functional synapses in this paradigm was important because the presence of MEF2 transcription factors have recently been shown to suppress synapse formation among cortical neurons (Flavell et al., 2006). In our paradigm, linking expression of MEF2CA to that of endogenous nestin, by use of the nestin/tk promoter to drive MEF2CA transcription, was a critical choice in our stable cell lines. Because nestin is only expressed at the NSC stage, once the MEF2CAESC-derived NPCs had differentiated into neurons, MEF2CA was downregulated coincident with nestin downregulation. Thus, after neuronal differentiation was initiated by MEF2CA, the transcription factor was apparently no longer necessary for continued neuronal development, and, in fact, its falling levels probably promote synapse formation in the cortex (Flavell et al., 2006). Our results show that MEF2CA-ESC-derived NPCs are a viable source of transplantable cells for investigating cell therapy treatments for neurological brain damage. Importantly, because of our molecularly directed differentiation of the cells to the stage of neuronal commitment, we never observed teratoma formation after transplantation of MEF2CA-ESC-derived NPCs $(n>50)$.

Additionally, behavioral studies after stroke on mice receiving MEF2CA-ESC-derived NPCs versus control neural progenitor cells showed that cell replacement therapy had a positive effect. Extinction of the fear response requires learning in the prefrontal cortex to extinguish the conditioned behavior. We found that transplantation resulted in significant improvement of this behavioral paradigm. These results imply that transplantation of progenitor cells expressing MEF2CA made a significant contribution to the recovery of mice after ischemic brain damage, either through creation of new synaptic circuits, secretion of trophic molecules, or a combination of the two.

Together, this report shows that forced expression of constitutively active MEF2C can keep neural progenitors alive while downstream differentiation events are directed along a neuronal lineage, and that such cells can be effective cell therapeutic agents in the treatment of ischemic brain injury. The results further suggest that MEF2C may possibly be permissive or even instructive for at least a component of the neurogenic program, and the so-called "default" pathway to neuronal development may re- quire MEF2 transcriptional activity because dominant-negative $\mathrm{MEF} 2 \mathrm{C}$ resulted in progenitor cell death. MEF2 is clearly not the only important transcription factor in neuronal differentiation, but it may represent a branch point in the pathway distinguishing "neural" progenitor from "neuronal" progenitor cell, at least in mouse cells. With this as a starting point, we have shown that mouse embryonic stem cells, treated as we have described, can be indefinitely expanded at a neuronal lineage-restricted stage of differentiation, in which teratoma formation is no longer a threat. These MEF2CA-ESC-derived NPCs can be successfully used for cell replacement therapy of neurological pathologies in an animal model system. Currently, a similar strategy is being tested in human ES cells as well.

\section{References}

Allen MP, Xu M, Linseman DA, Pawlowski JE, Bokoch GM, Heidenreich KA, Wierman ME (2002) Adhesion-related kinase repression of gonadotropin-releasing hormone gene expression requires Rac activation of the extracellular signal-regulated kinase pathway. J Biol Chem 277:38133-38140.

Alvarez-Buylla A, Lois C (1995) Neuronal stem cells in the brain of adult vertebrates. Stem Cells 13:263-272.

Armstrong RJ, Watts C, Svendsen CN, Dunnett SB, Rosser AE (2000) Survival, neuronal differentiation, and fiber outgrowth of propagated human neural precursor grafts in an animal model of Huntington's disease. Cell Transplant 9:55-64.

Bain G, Kitchens D, Yao M, Huettner JE, Gottlieb DI (1995) Embryonic stem cells express neuronal properties in vitro. Dev Biol 168:342-357.

Bibel M, Richter J, Schrenk K, Tucker KL, Staiger V, Korte M, Goetz M, Barde YA (2004) Differentiation of mouse embryonic stem cells into a defined neuronal lineage. Nat Neurosci 7:1003-1009.

Black BL, Olson EN (1998) Transcriptional control of muscle development by myocyte enhancer factor-2 (MEF2) proteins. Annu Rev Cell Dev Biol 14:167-196.

Black BL, Ligon KL, Zhang Y, Olson EN (1996) Cooperative transcriptional activation by the neurogenic basic helix-loop-helix protein MASH1 and members of the myocyte enhancer factor-2 (MEF2) family. J Biol Chem 271:26659-26663.

Boise LH, Gonzalez-Garcia M, Postema CE, Ding L, Lindsten T, Turka LA, Mao X, Nunez G, Thompson CB (1993) bcl-x, a bcl-2-related gene that functions as a dominant regulator of apoptotic cell death. Cell 74:597-608.

Buffo A, Rite I, Tripathi P, Lepier A, Colak D, Horn AP, Mori T, Gotz M (2008) Origin and progeny of reactive gliosis: a source of multipotent cells in the injured brain. Proc Natl Acad Sci USA 105:3581-3586.

Bull ND, Bartlett PF (2005) The adult mouse hippocampal progenitor is neurogenic but not a stem cell. J Neurosci 25:10815-10821.

Cao G, Pei W, Ge H, Liang Q, Luo Y, Sharp FR, Lu A, Ran R, Graham SH, Chen J (2002) In vivo delivery of a Bcl-xL fusion protein containing the TAT protein transduction domain protects against ischemic brain injury and neuronal apoptosis. J Neurosci 22:5423-5431.

Cao QL, Zhang YP, Howard RM, Walters WM, Tsoulfas P, Whittemore SR (2001) Pluripotent stem cells engrafted into the normal or lesioned adult rat spinal cord are restricted to a glial lineage. Exp Neurol 167:48-58.

Chen J, Li Y, Wang L, Lu M, Zhang X, Chopp M (2001) Therapeutic benefit of intracerebral transplantation of bone marrow stromal cells after cerebral ischemia in rats. J Neurol Sci 189:49-57.

Choi YB, Tenneti L, Le DA, Ortiz J, Bai G, Chen HS, Lipton SA (2000) Molecular basis of NMDA receptor-coupled ion channel modulation by $S$-nitrosylation. Nat Neurosci 3:15-21.

Chow SY, Moul J, Tobias CA, Himes BT, Liu Y, Obrocka M, Hodge L, Tessler A, Fischer I (2000) Characterization and intraspinal grafting of EGF/ bFGF-dependent neurospheres derived from embryonic rat spinal cord. Brain Res 874:87-106.

Craig CG, Tropepe V, Morshead CM, Reynolds BA, Weiss S, van der Kooy D (1996) In vivo growth factor expansion of endogenous subependymal neural precursor cell populations in the adult mouse brain. J Neurosci 16:2649-2658.

Doetsch F, Caillé I, Lim DA, García-Verdugo JM, Alvarez-Buylla A (1999) Subventricular zone astrocytes are neural stem cells in the adult mammalian brain. Cell 97:703-716. 
Esposito MS, Piatti VC, Laplagne DA, Morgenstern NA, Ferrari CC, Pitossi FJ, Schinder AF (2005) Neuronal differentiation in the adult hippocampus recapitulates embryonic development. J Neurosci 25:10074-10086.

Flavell SW, Cowan CW, Kim TK, Greer PL, Lin Y, Paradis S, Griffith EC, Hu LS, Chen C, Greenberg ME (2006) Activity-dependent regulation of MEF2 transcription factors suppresses excitatory synapse number. Science 311:1008-1012.

Flax JD, Aurora S, Yang C, Simonin C, Wills AM, Billinghurst LL, Jendoubi M, Sidman RL, Wolfe JH, Kim SU, Snyder EY (1998) Engraftable human neural stem cells respond to developmental cues, replace neurons, and express foreign genes. Nat Biotechnol 16:1033-1039.

Frankowski H, Missotten M, Fernandez PA, Martinou I, Michel P, Sadoul R, Martinou JC (1995) Function and expression of the Bcl-x gene in the developing and adult nervous system. NeuroReport 6:1917-1921.

Fricker RA, Carpenter MK, Winkler C, Greco C, Gates MA, Bjorklund A (1999) Site-specific migration and neuronal differentiation of human neural progenitor cells after transplantation in the adult rat brain. J Neurosci 19:5990-6005.

Gage FH, Kempermann G, Palmer TD, Peterson DA, Ray J (1998) Multipotent progenitor cells in the adult dentate gyrus. J Neurobiol 36:249-266.

Gleeson JG, Allen KM, Fox JW, Lamperti ED, Berkovic S, Scheffer I, Cooper EC, Dobyns WB, Minnerath SR, Ross ME, Walsh CA (1998) Doublecortin, a brain-specific gene mutated in human X-linked lissencephaly and double cortex syndrome, encodes a putative signaling protein. Cell 92:63-72.

Gleeson JG, Lin PT, Flanagan LA, Walsh CA (1999) Doublecortin is a microtubule-associated protein and is expressed widely by migrating neurons. Neuron 23:257-271.

Gonzalez-Garcia M, Garcia I, Ding L, O’Shea S, Boise LH, Thompson CB, Nunez G (1995) bclx is expressed in embryonic and postnatal neural tissues and functions to prevent neuronal cell death. Proc Natl Acad Sci USA 92:4304-4308.

Gotz M (2003) Doublecortin finds its place. Nat Neurosci 6:1245-1247.

Gu Z, Cui J, Brown S, Fridman R, Mobashery S, Strongin AY, Lipton SA (2005) A highly specific inhibitor of matrix metalloproteinase-9 rescues laminin from proteolysis and neurons from apoptosis in transient focal cerebral ischemia. J Neurosci 25:6401-6408.

Hoehn M, Kustermann E, Blunk J, Wiedermann D, Trapp T, Wecker S, Focking M, Arnold H, Hescheler J, Fleischmann BK, Schwindt W, Buhrle C (2002) Monitoring of implanted stem cell migration in vivo: a highly resolved in vivo magnetic resonance imaging investigation of experimental stroke in rat. Proc Natl Acad Sci USA 99:16267-16272.

Holmin S, Almqvist P, Lendahl U, Mathiesen T (1997) Adult nestinexpressing subependymal cells differentiate to astrocytes in response to brain injury. Eur J Neurosci 9:65-75.

Johansson CB, Svensson M, Wallstedt L, Janson AM, Frisen J (1999) Neural stem cells in the adult human brain. Exp Cell Res 253:733-736.

Kim WK, Choi YB, Rayudu PV, Das P, Asaad W, Arnelle DR, Stamler JS, Lipton SA (1999) Attenuation of NMDA receptor activity and neurotoxicity by nitroxyl anion, NO. Neuron 24:461-469.

Krainc D, Bai G, Okamoto S, Carles M, Kusiak JW, Brent RN, Lipton SA (1998) Synergistic activation of the $N$-methyl-D-aspartate receptor subunit 1 promoter by myocyte enhancer factor $2 \mathrm{C}$ and Sp1. J Biol Chem 273:26218-26224.

Krajewski S, Mai JK, Krajewska M, Sikorska M, Mossakowski MJ, Reed JC (1995a) Upregulation of bax protein levels in neurons following cerebral ischemia. J Neurosci 15:6364-6376.

Krajewski S, Blomqvist C, Franssila K, Krajewska M, Wasenius VM, Niskanen E, Nordling S, Reed JC (1995b) Reduced expression of proapoptotic gene $\mathrm{BAX}$ is associated with poor response rates to combination chemotherapy and shorter survival in women with metastatic breast adenocarcinoma. Cancer Res 55:4471-4478.

Kuhn HG, Winkler J, Kempermann G, Thal LJ, Gage FH (1997) Epidermal growth factor and fibroblast growth factor-2 have different effects on neural progenitors in the adult rat brain. J Neurosci 17:5820-5829.

Lei SZ, Pan ZH, Aggarwal SK, Chen HS, Hartman J, Sucher NJ, Lipton SA (1992) Effect of nitric oxide production on the redox modulatory site of the NMDA receptor-channel complex. Neuron 8:1087-1099.

Leifer D, Krainc D, Yu YT, McDermott J, Breitbart RE, Heng J, Neve RL, Kosofsky B, Nadal-Ginard B, Lipton SA (1993) MEF2C, a MADS/ MEF2-family transcription factor expressed in a laminar distribution in cerebral cortex. Proc Natl Acad Sci USA 90:1546-1550.
Li M (2002) Lineage selection for generation and amplification of neural precursor cells. Methods Mol Biol 185:205-215.

Li Y, Chopp M, Chen J, Wang L, Gautam SC, Xu YX, Zhang Z (2000) Intrastriatal transplantation of bone marrow nonhematopoietic cells improves functional recovery after stroke in adult mice. J Cereb Blood Flow Metab 20:1311-1319.

Lim DA, Fishell GJ, Alvarez-Buylla A (1997) Postnatal mouse subventricular zone neuronal precursors can migrate and differentiate within multiple levels of the developing neuraxis. Proc Natl Acad Sci USA 94:14832-14836.

Lindvall O, Hagell P (2000) Clinical observations after neural transplantation in Parkinson's disease. Prog Brain Res 127:299-320.

Lipton SA, Choi Y-B, Pan Z-H, Lei SZ, Chen H-SV, Sucher NJ, Singel DJ, Loscalzo J, Stamler JS (1993) A redox-based mechanism for the neuroprotective and neurodestructive effects of nitric oxide and related nitrosocompounds. Nature 364:626-632.

Liste I, García-García E, Bueno C, Martínez-Serrano A (2007) Bcl-X(L) modulates the differentiation of immortalized human neural stem cells. Cell Death Differ 14:1880-1892.

Longa EZ, Weinstein PR, Carlson S, Cummins R (1989) Reversible middle cerebral artery occlusion without craniectomy in rats. Stroke 20:84-91.

Lothian C, Lendahl U (1997) An evolutionarily conserved region in the second intron of the human nestin gene directs gene expression to CNS progenitor cells and to early neural crest cells. Eur J Neurosci 9:452-462.

Magavi SS, Leavitt BR, Macklis JD (2000) Induction of neurogenesis in the neocortex of adult mice. Nature 405:951-955.

Mao Z, Nadal-Ginard B (1996) Functional and physical interactions between mammalian achaete-scute homolog 1 and myocyte enhancer factor 2A. J Biol Chem 271:14371-14375.

Mao Z, Wiedmann M (1999) Calcineurin enhances MEF2 DNA binding activity in calcium-dependent survival of cerebellar granule neurons. J Biol Chem 274:31102-31107.

Mao Z, Bonni A, Xia F, Nadal-Vicens M, Greenberg ME (1999) Neuronal activity-dependent cell survival mediated by transcription factor MEF2. Science 286:785-790.

McKinsey TA, Zhang CL, Olson EN (2002) MEF2: a calcium-dependent regulator of cell division, differentiation and death. Trends Biochem Sci 27:40-47.

Modo M, Stroemer RP, Tang E, Veizovic T, Sowniski P, Hodges H (2000) Neurological sequelae and long-term behavioural assessment of rats with transient middle cerebral artery occlusion. J Neurosci Methods 104:99-109.

Modo M, Rezaie P, Heuschling P, Patel S, Male DK, Hodges H (2002) Transplantation of neural stem cells in a rat model of stroke: assessment of short-term graft survival and acute host immunological response. Brain Res 958:70-82.

Murray RC, Navi D, Fesenko J, Lander AD, Calof AL (2003) Widespread defects in the primary olfactory pathway caused by loss of Mash1 function. J Neurosci 23:1769-1780.

Nagy A, Rossant J, Nagy R, Abramow-Newerly W, Roder JC (1993) Derivation of completely cell culture-derived mice from early-passage embryonic stem cells. Proc Natl Acad Sci USA 90:8424-8428.

Nakatomi H, Kuriu T, Okabe S, Yamamoto S, Hatano O, Kawahara N, Tamura A, Kirino T, Nakafuku M (2002) Regeneration of hippocampal pyramidal neurons after ischemic brain injury by recruitment of endogenous neural progenitors. Cell 110:429-441.

Namiki J, Tator CH (1999) Cell proliferation and nestin expression in the ependyma of the adult rat spinal cord after injury. J Neuropathol Exp Neurol 58:489-498.

Naya FJ, Olson E (1999) MEF2: a transcriptional target for signaling pathways controlling skeletal muscle growth and differentiation. Curr Opin Cell Biol 11:683-688.

Oh YJ, Swarzenski BC, O’Malley KL (1996) Overexpression of Bcl-2 in a murine dopaminergic neuronal cell line leads to neurite outgrowth. Neurosci Lett 202:161-164.

Okabe S, Forsberg-Nilsson K, Spiro AC, Segal M, McKay RD (1996) Development of neuronal precursor cells and functional postmitotic neurons from embryonic stem cells in vitro. Mech Dev 59:89-102.

Okamoto S, Krainc D, Sherman K, Lipton SA (2000) Antiapoptotic role of the p38 mitogen-activated protein kinase-myocyte enhancer factor 2 transcription factor pathway during neuronal differentiation. Proc Natl Acad Sci USA 97:7561-7566. 
Okamoto S, Li Z, Ju C, Scholzke MN, Mathews E, Cui J, Salvesen GS, BossyWetzel E, Lipton SA (2002) Dominant-interfering forms of MEF2 generated by caspase cleavage contribute to NMDA-induced neuronal apoptosis. Proc Natl Acad Sci USA 99:3974-3979.

Ornatsky OI, Andreucci JJ, McDermott JC (1997) A dominant-negative form of transcription factor MEF2 inhibits myogenesis. J Biol Chem 272:33271-33278.

Parras CM, Schuurmans C, Scardigli R, Kim J, Anderson DJ, Guillemot F (2002) Divergent functions of the proneural genes Mash1 and Ngn2 in the specification of neuronal subtype identity. Genes Dev 16:324-338.

Paylor R, Tracy R, Wehner J, Rudy JW (1994) DBA/2 and C57BL/6 mice differ in contextual fear but not auditory fear conditioning. Behav Neurosci 108:810-817.

Piccini P, Brooks DJ, Bjorklund A, Gunn RN, Grasby PM, Rimoldi O, Brundin P, Hagell P, Rehncrona S, Widner H, Lindvall O (1999) Dopamine release from nigral transplants visualized in vivo in a Parkinson's patient. Nat Neurosci 2:1137-1140.

Reynolds BA, Weiss S (1992) Generation of neurons and astrocytes from isolated cells of the adult mammalian central nervous system. Science 255:1707-1710.

Roberts AJ, Krucker T, Levy CL, Slanina KA, Sutcliffe JG, Hedlund PB (2004) Mice lacking 5HT receptors show specific impairments in contextual learning. Eur J Neurosci 19:1913-1922.

Roth KA, Motoyama N, Loh DY (1996) Apoptosis of bcl-x-deficient telencephalic cells in vitro. J Neurosci 16:1753-1758.

Schulz RA, Chromey C, Lu MF, Zhao B, Olson EN (1996) Expression of the D-MEF2 transcription in the Drosophila brain suggests a role in neuronal cell differentiation. Oncogene 12:1827-1831.

Shalizi A, Gaudilliere B, Yuan Z, Stegmuller J, Shirogane T, Ge Q, Tan Y, Schulman B, Harper JW, Bonni A (2006) A calcium-regulated MEF2 sumoylation switch controls postsynaptic differentiation. Science 311:1012-1017.

Shihabuddin LS, Horner PJ, Ray J, Gage FH (2000) Adult spinal cord stem cells generate neurons after transplantation in the adult dentate gyrus. J Neurosci 20:8727-8735.

Skerjanc IS, Wilton S (2000) Myocyte enhancer factor 2C upregulates MASH-1 expression and induces neurogenesis in P19 cells. FEBS Lett 472:53-56.

Soriano SG, Lipton SA, Wang YF, Xiao M, Springer TA, Gutierrez-Ramos JC, Hickey PR (1996) Intercellular adhesion molecule-1-deficient mice are less susceptible to cerebral ischemia-reperfusion injury. Ann Neurol 39:618-624.

Sotres-Bayon F, Bush DE, LeDoux JE (2004) Emotional perseveration: an update on prefrontal-amygdala interactions in fear extinction. Learn Mem 11:525-535.

Svendsen CN, Clarke DJ, Rosser AE, Dunnett SB (1996) Survival and differentiation of rat and human epidermal growth factor-responsive precursor cells following grafting into the lesioned adult central nervous system. Exp Neurol 137:376-388.

Svendsen CN, Caldwell MA, Shen J, ter Borg MG, Rosser AE, Tyers P, Karmiol S, Dunnett SB (1997) Long-term survival of human central nervous system progenitor cells transplanted into a rat model of Parkinson's disease. Exp Neurol 148:135-146.

Terada N, Hamazaki T, Oka M, Hoki M, Mastalerz DM, Nakano Y, Meyer EM, Morel L, Petersen BE, Scott EW (2002) Bone marrow cells adopt the phenotype of other cells by spontaneous cell fusion. Nature 416:542-545.

Tropepe V, Hitoshi S, Sirard C, Mak TW, Rossant J, van der Kooy D (2001) Direct neural fate specification from embryonic stem cells: a primitive mammalian neural stem cell stage acquired through a default mechanism. Neuron 30:65-78.

Villa A, Snyder EY, Vescovi A, Martinez-Serrano A (2000) Establishment and properties of a growth factor-dependent, perpetual neural stem cell line from the human CNS. Exp Neurol 161:67-84.

Wang YF, Tsirka SE, Strickland S, Stieg PE, Soriano SG, Lipton SA (1998) Tissue plasminogen activator (tPA) increases neuronal damage after focal cerebral ischemia in wild-type and tPA-deficient mice. Nat Med 4:228-231.

White PM, Morrison SJ, Orimoto K, Kubu CJ, Verdi JM, Anderson DJ (2001) Neural crest stem cells undergo cell-intrinsic developmental changes in sensitivity to instructive differentiation signals. Neuron 29:57-71

Ying QL, Nichols J, Evans EP, Smith AG (2002) Changing potency by spontaneous fusion. Nature 416:545-548.

Yu YT, Breitbart RE, Smoot LB, Lee Y, Mahdavi V, Nadal-Ginard B (1992) Human myocyte-specific enhancer factor 2 comprises a group of tissuerestricted MADS box transcription factors. Genes Dev 6:1783-1798.

Zhang R, Xue YY, Lu SD, Wang Y, Zhang LM, Huang YL, Signore AP, Chen J, Sun FY (2006) Bcl-2 enhances neurogenesis and inhibits apoptosis of newborn neurons in adult rat brain following a transient middle cerebral artery occlusion. Neurobiol Dis 24:345-356. 